\author{
Danuta Sosnowska (D) https://orcid.org/0000-0001-6059-7548 \\ Uniwersytet Warszawski \\ d.sosnowska@uw.edu.pl
}

\title{
Galicja, która skłania do refleksji
}

\author{
(Alois Woldan, Studia galicyjskie, tłum. J. Dąbrowski, \\ J. Krzysztoforska-Doschek, Universitas, Kraków 2019, ss. 316)
}

\section{A Galicia that Inspires Contemplations}

Profesor Alois Woldan, od niedawna profesor emeritus Uniwersytetu Wiedeńskiego, jest postacią doskonale znaną w międzynarodowym środowisku slawistów. Na szczególną uwagę zasługuje jego wkład w badania w zakresie polonistyki i ukrainistyki, umiejętność szczególnie cenną stanowi komparatystyczne podejście do analizowanych tekstów, ściślej: narracji tworzących społeczne wyobrażenia, a współtworzonych przez owe teksty lub w nich ujawnianych. Do badań porównawczych Alois Woldan jest znakomicie przygotowany z uwagi na biegłość w wielu językach (w tym językach słowiańskich), a także znakomitą erudycję, dzięki której wydobywa z niepamięci autorów i dzieła nieobecne nawet $\mathrm{w}$ fachowych leksykonach. Literatura jest dla Woldana głównym przedmiotem analizy, jednakże jego badania na samej literaturze się nie zatrzymują: profesor ujawnia, w jaki sposób literackie, a nawet historyczne zapisy, tworzą wyobrażenia (reprezentacje), dzięki którym społeczności wiążą się z rzeczywistością, oswajają ją i rozumieją. I chociaż Profesor - w metodologii znakomicie zorientowany - nie obawia się sięgać po pojęcia i koncepcje, które dla humanistyki poddanej presji nowości nie są już dernier cri (Bachtinowski chronotop lub lieu de mémoire Pierre'a Nory), to zarazem jego badania są nowoczesne. Pokazują kulturowe i ideologiczne warunkowanie powstawania społecznych wyobrażeń. A takie podejście wymaga wzniesienia się ponad etnocentryczne narracje i rozważenia ich w szerokim kontekście innych przedstawień, innych kodów opowieści. 
Wskazane zalety prezentuje wydany niedawno zbiór artykułów Aloisa Woldana zatytułowany Studia galicyjskie ${ }^{1}$. Autor pisze we wstępie, że książka obejmuje teksty powstałe w ostatnich dziesięciu latach (s. 5). Oświetlają one z różnych stron fenomen zwany „literaturą galicyjską”, która, jak podkreśla Profesor, jest częścią piśmiennictwa polskiego, ukraińskiego, niemieckiego i żydowskiego (s. 5). Na marginesie dodać mogę, że istnieje też czeski aspekt „literatury galicyjskiej”, mający znaczenie z uwagi na dużą emigrację ukraińską, która w okresie międzywojnia znalazła gościnę w Czechosłowacji. Badacz rozumie „literaturę galicyjską" jako „dynamiczny i otwarty system, w którym trwale oddziałują na siebie najrozmaitsze komponenty - tematy, motywy, gatunki, języki, autorzy" (s. 5). Złożoną dynamikę tego systemu obrazują artykuły, które składają się na książkę. Woldan nie tylko poddaje analizie toposy, metafory i inne elementy tworzące galicyjskie narracje, ale także pokazuje ich powroty, czasem po dziesięcioleciach „uśpionego życia”. Temu zagadnieniu poświęcone są dwa frapujące studia: Konkurencyjne i komplementarne narracje o dziejach Lwowa - relacje z oblężenia miasta $w 1648 \mathrm{r}$. oraz Lwów jako antemurale christianitas $w$ latach I wojny światowej. Pierwszy tekst konfrontuje rozmaite kody opowieści o powstaniu Bohdana Chmielnickiego: z perspektywy obleganych we Lwowie Polaków i Żydów oraz napierających na nich Kozaków. W nielicznych momentach zazębiania się opowieści, gdy przywołują one te same fakty, widzimy, że jedno i to samo zdarzenie zyskuje inną wagę i sens w odmiennym kontekście.

Bardzo ciekawym tropem, wskazanym przez Profesora, jest powrót zainteresowania wydarzeniami z 1648 roku dwieście lat później, czyli w roku 1848 i latach następnych. Woldan poddaje analizie wiele powstałych wówczas tekstów, polskich i ruskich. Z jednej strony pokazuje, jak to, co odbiera się jako opowieść historyczną, choć beletryzowaną - Szkice historyczne Ludwika Kubali - posiłkowało się literaturą, aczkolwiek nie ujawniało jej jako źródła (wpływ antysielanek Szymona Zimorowica na interpretacje Kubali); z drugiej strony literatura poddawała narrację historyczną przekształceniom i odkształceniom, budując własne reprezentacje. Kubala w opisie oblężenia Lwowa nie heroizuje działań polskiego oręża, nie uwzniośla zachowań Jeremiego Wiśniowieckiego, który odebrał wojskowy awans i hojną nagrodę w zamian za obronę miasta, po czym potajemnie je opuścił. Wiśniowiecki w glorii męża opatrznościowego wkrótce pojawi się w Ogniem i mieczem Henryka Sienkiewicza i ta właśnie wizja przeniknie do polskiej wyobraźni.

Nie mniej zajmującym wątkiem jest marginalizacja udziału Żydów w ocaleniu Lwowa przed grabieżą i zniszczeniem: w tekstach galicyjskiego powieściopisarza i publicysty Jana Lama o roli Żydów wprawdzie się wspomina, ale w sposób minimalizujący ich zasługi, w rezultacie czego wszelkie dokonania i sukcesy przypisać można tylko Polakom. Nasycone antysemicką agitacją teksty

1 A. Woldan, Studia galicyjskie, posł. J. Purchla, tłum. J. Dąbrowski, J. Krzysztoforska-Doschek, Kraków 2019. Cytaty w tekście oznaczam numerami stron. 
Lama staną się, jak pisze Woldan, „idiomem, który wyklucza inne interpretacje historii" (s. 81).

Kontekstem dla polskiego kodu opowieści o powstaniu Chmielnickiego są teksty publikowane w prasie ruskiej, często o radykalnej, antypolskiej wymowie. Woldan przywołuje rozmaite źródła, ale jedno z nich zwraca szczególną uwagę: w polskim przekładzie tytuł brzmi Wytrzebienie Lachów na ziemiach ruskich latem $1648 \mathrm{r}$. Wiedeński slawista podkreśla zarówno ogromny obszar, uznawany przez anonimowego autora za ziemię ruską, jak i retorykę „oczyszczania” tej ziemi „z Polaków i innych nieruskich narodowości”. Komentując popularnonaukową Historię narodowa Rusi, która ukazała się w roku 1868 i zawierała przywołany powyżej tekst, Woldan stwierdza: „pojęcie czystki etnicznej jeszcze nie istniało, ale wywód anonimowego autora tego właśnie dotyczy"(s. 84).

Zatrzymajmy się przez chwilę przy tym temacie, pozwalając sobie na komentarz. Przełomowym rokiem, po którym obie narracje, polska i ruska, radykalizują się, a zarazem powracają do wydarzeń powstania Chmielnickiego traumatycznych dla polskiej pamięci, a konstytutywnych dla ukraińskiej tożsamości - jest rok 1848. To wtedy na forum publicznym Rusini przedstawili kulturowe i polityczne aspiracje, które dojrzewały już dużo wcześniej, choć Polacy nie chcieli ich dostrzegać. Także tym razem strona polska nie uznała powagi wystąpienia Rusinów i nieuchronności ich narodowych dążeń. Upierała się, że przyczyną ruskich manifestacji jest akcydentalny fakt (austriackie intrygi), a nie logika historycznych wydarzeń. Zarazem druga strona z satysfakcją opisywała „oczyszczanie” ziemi z Polaków podczas powstania Chmielnickiego. Nie minie sto lat, a to, co zwiastuje konflikt obu narracji, nabierze tragicznej realności podczas polsko-ukraińskiej wojny na Wołyniu i towarzyszącej jej rzezi ludności cywilnej. Do dziś polscy i ukraińscy historycy spierają się o przyczyny tych wydarzeń, skalę tragedii i odpowiedzialność 2 . Zaś w pamięci świadków, o ile została zapisana, bo przecież większość już nie żyje, straszliwe przeżycia wydają się pojawiać nie wiadomo czemu, po latach dobrego sąsiedztwa.

Warto w tym miejscu przytoczyć myśl wybitnego teoretyka historiografii i narratywisty, który pisał: „Przedstawieniom historycznym zaprzecza nie tyle sama rzeczywistość historyczna, co inne przedstawienie historyczne”3. Wspomniana już nowoczesność Studiów galicyjskich polega między innymi na konfrontowaniu narracji formułowanych na galicyjskim obszarze, a zarazem uzmysławianiu czytelnikowi, że rozmaite opowieści, i literackie, i te uznawane za historyczne, stawały się, jak pisał Frank Ankersmit, „narracyjnymi organizacjami wiedzy". Wiedzy, którą społeczeństwo chciało przyjmować i którą uznawało za przekonujący sposób wyjaśniania świata.

2 Zob. między innymi recenzję Grzegorza Motyki z wydanej w roku 2011 książki Wołodymyra Wiatrowycza. G. Motyka, Nieudana ksiażka, „Nowa Europa Wschodnia” 2012, nr 2.

3 F. Ankersmit, Narracja, reprezentacja, doświadczenie. Studia z teorii historiografii, red., tłum., wstęp E. Domańska, Kraków 2004, s. 159. 
Alois Woldan sporo uwagi poświęca koncepcji antemurale, konstytutywnej dla polskiego dyskursu. Przypomina jednak, że Polacy nie mieli wyłączności na pojęcie, bowiem posiłkowali się nim również Kozacy, uważający, że stanowią pierwszy mur w obronie chrześcijaństwa przed nawałą turecką. Polacy twierdzili, że kozackie zaczepki i najazdy na sułtanat przynosiły więcej szkody niż pożytku. Kozacy trzymali się swoich racji. Konkurencja dyskursów oznaczała także konkurencję zasług, a w konsekwencji rywalizujące wizje roli na terenach pogranicznych. Do polskiej świadomości społecznej praktycznie nie przebiła się wiedza o kozackich aspiracjach związanych z ideą przedmurza chrześcijaństwa.

Niezaprzeczalną wartością studiów Woldana jest prezentowanie pojęć konstytutywnych dla polskiego dyskursu w ich „długim trwaniu”. Autor pokazuje, jak koncept antemurale - początkowo rezerwowany dla rubieży Rzeczypospolitej - stopniowo zaczyna funkcjonować w obszarze Galicji i rozwija dalsze konotacje oraz metafory między innymi twierdzy i bastionu. Tak potwierdza swój charakter „konstruktu ideologiczno-politycznego” (s. 97, 98). Elementem wizji antemurale staje się Lwów, zyskujący też miano semper fidelis, a wojskową retoryką objęty zostanie Uniwersytet Lwowski. Profesor Woldan przedstawia ekskluzywność dyskursu związanego z uczelnią, który wykluczał wzmianki o żądaniach Ukraińców domagających się własnej Alma Mater we Lwowie i/lub równouprawnienia języka ruskiego na Uniwersytecie.

O tych sprawach w Polsce nadal rzadko się pisze, a jeśli już, to wiedzę przekazują prace specjalistyczne. Dodajmy więc, znowu tytułem dygresji, że od 1901 roku demonstracje ukraińskich studentów na Uniwersytecie Lwowskim stawały się coraz gwałtowniejsze, zarazem bardziej zaciekły był opór polskiej strony, która nie chciała się zgodzić się na żadne koncesje na rzecz edukacyjnych żądań Ukraińców. Pojawiały się wprawdzie polskie głosy, które wyrażały zrozumienie dla ukraińskich pretensji, ale należały do rzadkości. Stanisław Kot wspomina:

zwołano polski wiec ogólnoakademicki dla zwalczania ukraińskiego postulatu równouprawnienia w urzędowaniu i wykładach języka ukraińskiego z polskim. Uważałem to za naturalne żądanie, wszak Ukraińcy byli na tej ziemi tubylcami, a nie widziałem żadnej szkody w udzieleniu im różnych praw w szkolnictwie na wszystkich stopniach ${ }^{4}$.

To stanowisko należało do odosobnionych, a Kot został na wiecu pobity pałkami przez polskich studentów narodowców. Lała się więc krew, byli ranni, nawet zabici. Retoryka „twierdzy” czy „bastionu” przekładała się na brutalną rzeczywistość polityczną.

Jak dalece te kwestie są zapoznane, czytelnik książki profesora Woldana przekona się, próbując dowiedzieć się czegoś więcej o przywołanej przez autora tak zwanej „krwawej immatrykulacji z roku 1907” (s. 94). Trudno uzyskać

4 S. Kot, Wspomnienia, „Zeszyty Historyczne” (Paryż) 1968, z. 14, s. 146. 
informacje na ten temat, gdyż dominantą polskich opowieści jest dokonane w tym okresie zabójstwo namiestnika Andrzeja Potockiego. Tym ważniejsze są zasługi austriackiego slawisty, który konfrontuje nas nie tylko z polskimi miejscami pamięci (które przynależą też do pamięci innych - vide Lwów), ale stawia przed nami lustro pamięci wypartej.

Zwróćmy uwagę, że w trzytomowej, i co warto podkreślić - cennej pracy poświęconej dziejom polskiej inteligencji, tom trzeci, pióra Magdaleny Micińskiej, Inteligencja polska na rozdrożach. 1864-1918, w ogóle nie odnosi się do napięć na Uniwersytecie Lwowskim. A przecież jeszcze przed odzyskaniem niepodległości na lwowskiej uczelni działali wybitni profesorowie, twórcy polskiej nauki i wychowawcy równie wybitnych następców. W tym czasie musieli konfrontować się z żądaniami ukraińskich studentów i w konkretnej sytuacji określać swoją rolę badaczy i wychowawców oraz zadania uniwersytetu. W interesującym nas okresie pracował na lwowskiej uczelni popularny historyk Szymon Askenazy (mianowany na stanowisko profesora w 1906 roku); Oswald Balzer, wybitny historyk ustroju i prawa polskiego - na Uniwersytecie Lwowskim w latach 1887-1933; Józef Nusbaum-Hilarowicz, twórca lwowskiej szkoły zoologicznej, który założył jeden z najnowocześniejszych badawczych ośrodków zoologicznych w Europie, a pracował na uczelni od 1906 roku do śmierci w 1917; Kazimierz Twardowski, twórca lwowskiej szkoły filozofii (lista jego wybitnych uczniów jest bardzo długa, wymienię tylko kilka postaci: Władysław Tatarkiewicz, Tadeusz Kotarbińskich, Kazimierz Ajdukiewicz, Stefan Banach, Stanisław Leśniewski, Juliusz Kleiner, Manfred Kridl, Stanisław Łempicki, Zygmunt Łempicki). Kazimierz Twardowski piastował funkcję dziekana Wydziału Filozoficznego Uniwersytetu Lwowskiego w latach 1901/1902 i 1904/1905, a rektora w latach 1914-1917, a więc wtedy, gdy na uniwersytecie wrzało. W książce Magdaleny Micińskiej Twardowski wspomniany jest raz, jako propagator idei Henry'ego Bergsona na łamach prasy polskiej.

Poruszam to zagadnienie, gdyż potwierdza ono nie tylko trafność, ale i doniosłość słów Woldana. Pisze on:

Dyskurs o antemurale pokazuje też jeszcze jeden aspekt, typowy dla każdego dyskursu - związek między narracją a siłą. Pozwala wnioskować, kto jest silniejszy w grach językowych. W interesującym nas okresie silniejsza była strona polska i to ona dyktowała reguły dyskursu. Zarazem jednak widać też, jak strona słabsza, ukraińska, próbuje przyswoić sobie reguły tej gry i wykorzystać je do własnych celów (s. 112).

W grach językowych budujących wielopostaciowy obraz Galicji, ale też potwierdzających własne roszczenia, uczestniczyli także Rosjanie, którzy za pomocą czysto lingwistycznych zabiegów starali się pokazać Lwów jako „wiecznie rosyjskie miasto" (s. 100). Ważnym graczem byli Niemcy, budujący - jak Roth obraz Lwowa jako „miasta zatartych granic”, miasta, „które nie jest koniecznie 
związane z państwami narodowymi” (s. 107). Można postawić hipotezę, że ten wariant „tekstu miasta”, który Woldan analizuje na przykładzie prozy Jurija Andruchowycza i Andrzeja Stasiuka, wykazując, iż ich narracje wznoszą się ponad kod narodowy, ma swoje korzenie właśnie w tekstach Rotha. A zarazem zakorzenienie w tożsamości regionalnej, a nie narodowej. Woldan pokazuje też inne lektury tekstu miasta, sięgając do „klasyków” polskiej literatury galicyjskiej (Andrzeja Stojowskiego, Andrzeja Kuśniewicza). Na oczach czytelnika ujawnione zostają zasady funkcjonowania mitu Galicji, a zarazem obraz Galicji jako repetytorium miejsc pamięci.

Narracja niemiecka na temat Galicji i Lwowa pokazywana jest przez austriackiego slawistę w kilku odsłonach, które z jednej strony przedstawiają to, czego Polacy nie chcieli dostrzegać, z drugiej strony ujawniają niemieckie uprzedzenia i stereotypy (Franz Kratter). Woldan przytacza relację z podróży znanego niemieckiego pisarza Alfreda Döblina, wydaną w roku 1926. Zacytuję fragment przywołany przez Woldana w Studiach galicyjskich:

Kazimierz Wielki zniszczył gród Daniła i zbudował nowy Lwów. Ale Ukraińcy nie uznają tego faktu - polskiego Lwowa. Naród ukraiński żyje rozdarty między Rosjanami a Polakami i nie znajduje spokoju. Rozmawiałem z ludźmi w mieście. Mam wrażenie, że toczy się tu ukryta, ale bardzo intensywna walka narodów (s. 110).

Powiedziałabym, że Döblin, dokonując lektury miasta Lwowa, zastosował metodę, którą Louis Althusser nazwał „lekturą symptomalną”. Pod powierzchnią zwykłej lektury miasta, zdominowanej przez polską narrację, odkrył to, co w dominującym tekście nieobecne, „niewidzialne”. Althusser pisał: „niewidzialny element pola widzialności to na ogół nie cokolwiek - byle zewnętrzne i obce w stosunku do widzialności określonej przez to pole. Widzialność określa niewidzialność jako swoją niewidzialność, swoje tabu wzrokowe $(\ldots)^{5}$.

Czytanie przez Woldana galicyjskich narracji wyrasta z tropienia tego, co jest „tabu wzroku” odbijane w tabu narracji. Taką funkcję - demaskacji - pełni tekst Döblina. Ludzie, żyjący we Lwowie w okresie międzywojennym, a także wcześniej, nie mogli nie dostrzegać „walki narodów”, o której pisał niemiecki eseista. Chyba że była ona spychana w obszar tego, co Althusser nazywał „ślepa plamką”. Tak reagowała strona polska - albo milczeniem, albo dyskredytacją przeciwnika. Nie było mowy o „walce narodów”: przeciwko narodowi polskiemu powstawał „ukraiński żywioł”, „wichrzyciele” lub po prostu „hajdamacy". Woldan przywołuje tekst Stanisława Wasylewskiego zatytułowany Lwów i odgrywający rolę swego rodzaju przewodnika po mieście. Badacz pisze:

W całej książce nie ma ani słowa wzmianki o Ukraińcach, choć autor dostrzega inne, niepolskie grupy ludności, jak Ormianie czy Żydzi. „Wielonarodowy

\footnotetext{
5 L. Althusser, É. Balibar, Czytanie „Kapitatu”, tłum. W. Dłuski, Warszawa 1975, s. 48.
} 
charakter" jest potrzebny miastu jako symbolowi odrodzonego państwa polskiego co najwyżej jako frazes, historyczny ornament. Opowieść o polskim patriotyzmie nie pozwala zaistnieć opowieści o patriotyzmie ukraińskim (s. 104).

Jeden z zabiegów służących spychaniu ukraińskiego patriotyzmu w obszar niewidzianego ujawni się w tak ważnej dla Polaków opowieści o bohaterstwie Orląt Lwowskich. Woldan zwraca uwagę, że „w opowieści o walkach w listopadzie 1918 roku nie mówi się ani słowa, z kim te dzieci walczyły, kto naruszył polskie granice i integralność ojczyzny, przed kim trzeba było tego miasta bronić" (s. 103). Przywołuje słowa amerykańskiego slawisty, Georga Grabowicza, dotyczące „dematerializacji innego, obcego”, „strategii dopuszczającej tylko polski punkt widzenia” (s. 103).

Trudno nie zgodzić się z powyższym stanowiskiem, ale należy zwrócić uwage na potencjalne niebezpieczeństwo jego złej interpretacji. Dostrzeżenie i uznanie odmiennych punktów widzenia oraz narracji różnych od własnej nie powinno w moim przekonaniu - skutkować beztroskim dezawuowaniem narodowej historii. Generalnie zgadzam się z tezą wyrażoną przez Boya Żeleńskiego w głośnej książce Brązownicy, że historia literatury nie powinna zmieniać się w hagiografię. To samo można odnieść do historii jako takiej. Jestem jednak przekonana, że każdy naród potrzebuje pamięci o heroizmie swych przodków, dumy z ich patriotyzmu, a nawet patosu opowieści o dziejach. Lekceważenie tej potrzeby i promowanie zamiast niej na przykład wartości obywatelskich (cennych, ale nie w znaczeniu ich wymienności) lub - co gorsza - nastawione na sensację „demaskowanie" bohaterów jest ryzykowne. A to dlatego, że powszechna, naturalna potrzeba godności Ojczyzny i dumy z niej może stać się, ze strachu przed „wywichniętym patriotyzmem”, polem pustym. A tam błyskawicznie zagnieżdżą się ekstremiści. Antidotum nie będzie jednak trzymanie się matecznika narodowych opowieści. Punkt ciężkości rozwiązania tego problemu leży w zmianie wzorców fabularyzacji dziejów, tak by uznając własny patriotyzm, nie korzystały ze strategii dematerializacji lub dyskredytacji przeciwnika. Nie mamy wtedy do czynienia ze wzorcem pokonania zła przez dobro, ale z tragiczną konfrontacją nierozumiejących się racji.

Woldan zwraca uwagę na metaforę serca obecną w polskim i ukraińskim dyskursie na temat Lwowa (s. 108). Konkluzja płynąca z rozważań na temat używania przenośni przez obie strony jest jasna: nie porzucimy wojennej retoryki bez uznania dwoistości duszy Lwowa.

Książkę tak bogatą w zagadnienia i problemy, jaką są Studia galicyjskie, można rozważać na różne sposoby i nie sposób wyczerpać jej tematyki nawet w długiej recenzji. Chciałabym jednak poruszyć jeszcze dwie kwestie, wskazane przez autora, a warte dalszych badań. Pierwsza, to temat „nafty” w literaturze galicyjskiej. Społeczne, kulturowe, a nawet polityczne konsekwencje odkrycia złóż ropy naftowej w Borysławiu znalazły swoje literackie odzwierciedlenie w piśmiennictwie polskim, ukraińskim i żydowskim. Przy tej okazji Woldan 
przywraca pamięci osobę żydowskiego pisarza, Hermana Blumenthala - nie z uwagi na artystyczną wartość jego tekstów, ale po to, by uobecnić także ten punkt widzenia. Wieloaspektowe ukazywanie zagadnienia biedy i bogactwa oraz patologii społecznych wywołanych boomem gospodarczym prowadzi autora Studiów... do wniosku, że tropienie winnych zła, jakie przyniosło Borysławskie odkrycie, prowokowało „unarodowienia” problemów społecznych, to znaczy na problemy społeczne odpowiadano argumentami narodowymi (s. 131). To oczywiście podsycało nastroje zarówno antypolskie, jak i antyżydowskie. Przywołany przez Woldana Blumenthal nie uległ tej pokusie: nie oczyścił żadnego narodu kosztem przepchnięcia win na inną wspólnotę. Wydaje się, że galicyjskie narracje na temat modernizacji, kapitału, własności i władzy, oglądane z perspektywy różnych dyskursów, to obszar badań, gdzie jeszcze wiele jest do zrobienia.

Drugą kwestią, do której chciałabym się odnieść, jest koncepcja badań komparatystycznych, wykorzystana przez Woldana w Studiach galicyjskich. Nie mnoży on metodologicznych wywodów ponad potrzebę. Na szczęście, bo dyskusje komparatystów nad komparatystyką zbyt często sprawiają wrażenie jałowych, w przeciwieństwie do bogatych możliwości zastosowania badań porównawczych w praktyce. Austriacki slawista informuje czytelnika, że nie bardzo interesują go genetyczne powiązania pomiędzy tekstami. Co więcej, najciekawsze są jego zdaniem przypadki, gdzie występuje podobieństwo, choć nie ma bezpośrednich odniesień ani potwierdzeń, kto czyje utwory czytał lub słyszał o nich (s. 138-139). Teksty różnej proweniencji: polskie, ukraińskie, niemieckie, żydowskie tworzą archipelag, po którym Woldan podróżuje, pokazując podobieństwa „flory i fauny” owych literackich wysp. Tyle że „florę i faunę” zastępują metafory, toposy, tematy budujące odosobnione, a jakże często zbliżone narracje. To niezwykle ważna praktyka. We wstępie do Studiów galicyjskich Woldan pisze, że książka różni się od wcześniejszego niemieckiego wydania poświęconego przyczynkom do literatury galicyjskiej (s. 6). To, co wyróżnia polską edycję, to jej polonistyczne nastawienie. Profesor podkreśla jednak, że „(...) nawet podchodząc do literackiego fenomenu Galicji z perspektywy polonistycznej, musimy poważnie nastawić się na spotkanie z innymi językami i literaturami” (s. 6). To ważna uwaga i... zachęta. Jednogłosowa Galicja najczęściej będzie uboga i karykaturalna, a „zewnętrzny” ogląd innych w Galicji stanie się parodią wielokulturowości.

Uwagi Woldana na temat posługiwania się metodologią komparatystyczną zawierają jeszcze jedno istotne założenie. Autor jest literaturoznawcą, często wiernym tradycyjnym badaniom filologicznym, pisze jednak, że obok kategorii kontekstów literackich jest też szerszy kontekst, pozaliteracki, historyczno-społeczny (s. 139) I ten właśnie kontekst autor ujawnia, także wtedy, gdy wydawałoby się - pisze „tylko” o literaturze. Pokazuje, jak narracje literackie tyleż obrazują, co kształtują sposoby myślenia; jak budują obraz „rzeczywistości” 
chcianej oraz wykluczania z niej tego, co niepożądane. Słowem, ujawniają to, co z pola widzenia zostało zepchnięte w obszar „ślepej plamki” (Althusser).

Można o tej bogatej książce pisać jeszcze długo: o jej polsko-czeskich tropach, o czytaniu sacrum w tekstach Jerzego Harasymowicza i pokazywaniu ukraińskiego kontekstu dla wierszy polskiego poety. Można pisać długo, tylko po co? Zamiast wywodów recenzenta niech czytelnik sięgnie po książkę. Pracę dojrzałą, bo autor nie boi się ani niemodnych tematów (Harasymowicz), ani zapomnianych pisarzy (Blumenthal) - wpisuje ich i wielu innych w galicyjski wielogłos. A tym samym uświadamia, że choć stałym czynnikiem polskiej tradycji jest wciąż przywoływana wielonarodowość, wielokulturowość i wieloreligijność, to zarazem wiele jeszcze mamy w tych obszarach do poznania i do zrozumienia. 